\title{
Taman Wisata Kuliner Dengan Pendekatan Arsitektur Metafora Di Kota Surakarta
}

\author{
Atikasita Armin Putri, Widi Suroto, Rachmadi Nugroho \\ Program Studi Arsitektur \\ Universitas Sebelas Maret Surakarta \\ Email : atikasitaap@yahoo.com
}

\begin{abstract}
Nowadays, culinary tourism is growing very rapidly. Eating and drinking are not only a basic need but also become one of the tourist destinations. Solo city is one of the cities that have potential in the development of culinary tourism. Solo city that has its own identity as a city of culture, has also been named as the first rank cities culinary tourism destinations in Indonesia. The government also has a plan to increase the culinary center at Solo in the year 2017-2019. The planned culinary center have to maintain a culinary hallmark of of Solo, so the plan need methods to achieve those goals. Therefore, the approach used as a metaphor of architecture appropriate method in the design of container culinary tourism. Architectural metaphor used is combined metaphor which combination of tangible metaphor and intangible metaphor.Tangible metaphor will be applied in the form of forms that act as a culinary hallmark visualization Solo with the aim to attract visitors, while intangible metaphor will be applied as forming distinctive atmosphere is non-visual to reinforce the impression of the culinary Solo.
\end{abstract}

Keywords: Culinary Tourism, Food Tourism, Intangible Metaphor Architecture, Metaphor Architecture, Tangible Metaphor Architecture

\section{PENDAHULUAN}

Wisata kuliner pada masa kini berkembang sangat pesat. Tidak dapat dipungkiri, pada dasarnya makan dan minum merupakan kebutuhan pokok manusia. Dengan perkembangan jaman, makan dan minum tidak hanya sebagai kebutuhan pokok tapi juga menjadi menjadi salah satu tujuan dalam kegiatan pariwisata.

Indonesia tidak diragukan lagi dalam bidang kuliner. Beraneka ragam suku dan budaya menimbulkan ciri khas tersendiri di masing-masing daerah. Begitu pula dengan ciri khas di bidang kuliner. Tidak hanya beragam jenisnya, kelezatan kuliner Indonesia juga telah diakui oleh dunia dengan pengakuan nasi goreng dan rendang sebagai makanan terenak sedunia (CNNGo, 2011).

Kota Surakarta, yang biasa akrab disebut Solo, memiliki potensi besar dalam pengembangan wisata kuliner. Dari segi kuliner, Solo sangat dikenal sebagai salah satu kota dengan kuliner yang unik dan beragam. Wisatawan yang berkunjung ke Solo hampir tidak pernah melewatkan kuliner-kuliner yang disajikan di kota ini. Mulai dari makanan basah seperti Nasi Liwet, Tengkleng, Selat Solo, Gudeg Ceker, Timlo Solo, Sambel Tumpang, Sate Kere, Cabuk Rambak, dan lainlain. Ada juga hidangan ringan yang sangat identik dengan Solo yaitu Serabi Solo, Intip, Abon dan Roti Mandarin. Begitu juga minuman khas Solo, yaitu Gempol Pleret, Dawet Ayu dan Tahok (Dinas Kebudayaan dan Pariwisata Kota Pariwisata, 2016)

Keberanekaragaman kuliner khas Solo yang sulit ditemukan di tempat lain menjadikan daya tarik tersendiri bagi wisatawan untuk berkunjung ke Solo. Kota Solo selalu mempertahankan kekhasan budaya dan kuliner karena memiliki visi misi pariwisata, yaitu "Solo ke Depan adalah Solo Tempo Dulu".

Kekuatan dari visi misi pengembangan pariwisata Kota Solo tersebut menjadi salah satu keistimewaan yang menjadikan Kota Solo dinobatkan sebagai peringkat pertama kota destinasi wisata kuliner di Indonesia (Asfar, 2016). Prestasi tersebut baru saja ditetapkan oleh Kementerian Pariwisata Indonesia pada bulan Maret 2016 melalui hasil survey Tim 
Percepatan Pengembangan Destinasi Wisata Kuliner Indonesia. Penetapan Solo sebagai kota destinasi wisata kuliner terpopuler di Indonesia didasari oleh penilaian dari segi keistimewaan kuliner Kota Solo yang dinilai sangat beragam, lengkap dan memiliki ciri khas dibanding kota lainnya. Penobatan tersebut akan dimanfaatkan oleh Dinas Kebudayaan dan Pariwisata Kota Solo untuk terus mengembangkan potensi destinasi wisata kuliner. Salah satu rencana dari Dinas Kebudayaan dan Pariwisata Kota Solo adalah mengembangkan sentra kuliner di Solo, yang tahun ini hanya memiliki satu sentra kuliner yaitu Galabo, akan ditargetkan adanya penambahan 2-4 sentra kuliner di Kota Solo pada tahun 2017-2019.

Perencanaan perancangan area wisata kuliner akan menjadi objek wisata Kota Surakarta yang harus memperhatikan nilainilai kekhasan Kota Surakarta, terlebih dengan predikat Kota Surakarta yang terkenal sebagai kota budaya. Objek ini memperhatikan bagaimana cara memunculkan kembali dan menguatkan kesan atau suasana yang menjadi ciri khas kuliner Kota Solo yang telah terbentuk sejak jaman dahulu, dengan tujuan pengunjung yang datang ke dalam objek ini akan dapat langsung mengenal, memahami dan merasakan kesan atau suasana tersendiri bahkan dapat mengingatkan pada kenangankenangan Kota Solo, khususnya di bidang kuliner.

Selain itu, area wisata kuliner tersebut merupakan wadah yang tentunya akan terbentuk unsur bisnis di dalamnya. Dalam sebuah konteks bisnis, juga perlu adanya ciri khas tersendiri yang dapat membentuk kesan khusus pada bangunan tersebut dengan tujuan dapat menarik minat pengunjung. Dari ketertarikan tersebut akan menjadi langkah untuk mendatangkan pengunjung dan keuntungan, sehingga menjadi tujuan dari kesuksesan wadah bisnis. Terlebih dalam fungsi objek yang merupakan sebuah pusat kumpulan seluruh kuliner khas Kota Surakarta, sehingga objek ini akan menjadi salah satu simbol kota dan tujuan wisata kota yang harus mempunyai identitas tersendiri.

Untuk itu, akan digunakan Arsitektur Metafora sebagai pendekatan desain. Arsitektur Metafora dipilih sebagai karena Arsitektur Metafora merupakan metode arsitektur dengan pengaplikasian ide dalam bentuk visual dan non visual yang sangat mudah ditangkap dan dirasakan maknanya oleh orang lain. Penerapan Arsitektur Metafora disesuaikan berdasarkan jenisnya yang dibedakan menjadi tiga jenis, yaitu Metafora Konkrit, Metafora Abstrak dan Metafora Kombinasi. Dari segi visual/konkrit, Arsitektur Metafora akan dimanfaatkan sebagai pembentuk kesan objek untuk menarik minat pengunjung. Sedangkan, sebagai pembentuk kesan atau suasana yang menjadi ciri khas Kota Solo akan lebih ditekankan pada penerapan Arsitektur Metafora secara non visual/abstrak, sehingga dalam penerapan pada objek akan menggunakan Arsitektur Metafora Kombinasi.

\section{METODE}

Metode desain yang digunakan dalam proses perencanaan dan perancangan Taman Wisata Kuliner adalah metode apresiatif atau deskriptif kualitatif, yang meliputi 3 aspek, yaitu tahap ide/konsep, tahap transformasi dan tahap fisik/produk (Lestari, 2013).

Pada tahap ide/konsep merupakan tahap awal dalam metode apresiatif yang merupakan pemberangkatan ide awal dengan menggali potensi hingga menentukan gagasan awal. Ide/konsep Taman Wisata Kuliner berawal dari penggalian potensi kuliner yang semakin berkembang dan memiliki potensi tersendiri di Kota Surakarta. Dari penggalian potensi dan penentuan gagasan awal tersebut menjadi latar belakang desain yang kemudian menentukan tujuan dan sasaran desain. Dari penentuan tujuan dan sasaran, dilakukan tahap selanjutnya kajian pustaka dan kajian preseden sebagai dasar perancangan arsitektural. Kajian pustaka dan kajian preseden dilakukan melalui penggalian teori dari buku dan artikel terkait Taman Wisata Kuliner dan Arsitektur Metafora.

Tahap transformasi merupakan tahap yang diawali dengan penggalian data terkait Taman Wisata Kuliner, Arsitektur Metafora dan Kota Surakarta. Penggalian data ini dilakukan dengan melakukan survey lapangan. Selain untuk penggalian data, survey lapangan juga dilakukan untuk penentuan lokasi tapak dan mengumpulkan data mengenai keadaan 
lingkungan dan potensi sekitar tapak atau lokasi terpilih.

Dari data yang didapat, dilanjutkan dengan penentuan kriteria desain serta merumuskan konsep desain. Dalam tahap analisa dilakukan melalui proses penguraian data-data dan pembuatan gambaran sebagai media analisa. Tahapan analisa dikelompokkan menjadi analisa programatik dan analisa pemrograman arsitektur.

Tahap terakhir adalah tahap fisik produk yang dibagi menjadi tahap sintesa dan apresiasi berdasar konsep. Tahap sintesa bentuk adalah penyatuan keseluruhan data dan hasil analisa untuk mencapai tujuan dan sasaran yang sesuai dengan pendekatan Arsitektur Metafora.

\section{ANALISIS}

\subsection{Analisis Arsitektur Metafora pada Objek Rancang Bangun}

1. Tujuan

Bentuk yang dapat menggambarkan fungsi objek secara visual, dan suasana khas kuliner Kota Solo secara non visual (Anthony C. Antoniades, 1992).

2. Dasar pertimbangan

a. Tujuan objek desain untuk dapat mengkomunikasikan fungsi objek secara visual guna menarik minat pengunjung.

b. Tujuan objek desain untuk membentuk suasana khas dalam pewujudan non visual.

\subsection{Analisis Tapak}

1. Tujuan

Tapak terpilih yang sesuai dengan kriteria yang telah ditetapkan.

2. Dasar Pertimbangan

a. Sesuai dengan perencanaan pengembangan wilayah Kota Surakarta berdasarkan Rencana Tata Ruang Wilayah Kota Surakarta yang merupakan wilayah pariwisata, budaya dan perdagangan (Walikota Surakarta, 2012).

b.Terletak pada lokasi yang strategis yaitu pusat kota dengan tingkat keaktifan masyarakat yang masih tinggi dan menjadi wilayah tujuan wisatawan. c. Akses mudah dicapai oleh kendaraan dan penjalan kaki.

d.Potensi lokasi yang berdekatan dengan objek-objek wisata lainnya dan terdapat aliran Kali Pepe di bagian tapak sehingga menjadi potensi tersendiri.



Gambar 1. Tapak Terpilih

Tapak memiliki luas $10.250 \mathrm{~m}^{2}$. Seperti pada Gambar 1 menunjukkan batasan tapak yaitu sebelah utara merupakan pertokoan, sebelah selatan merupakan Bank Negeri Indonesia dan pertokoan, sebelah timur merupakan Jalan Suryopranoto dan sebelah barat merupakan Jalan Arifin.

\subsection{Analisis Pencapaian}

\section{Tujuan}

Main enterance dan side entrance yang sesuai dengan kriteria pencapaian (Gambar 2).

2.Dasar pertimbangan

a. Sesuai dengan teori pencapaian.

b. Memperhatikan aksesibilitas menuju tapak.

c. Memperhatikan kemudahan pencapaian dari jalan utama.

d. Tidak mengganggu pergerakan lalu lintas.

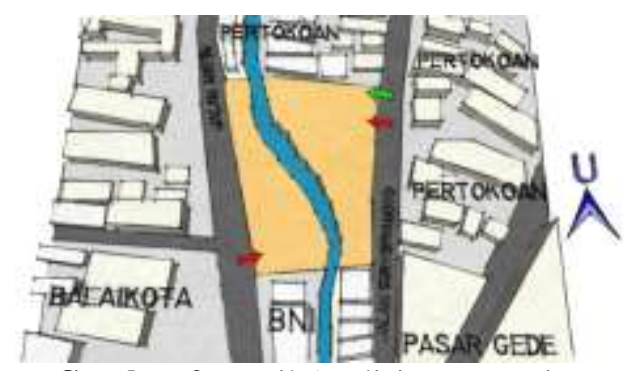

Gambar 2. Hasil Analisis Pencapaian

\subsection{Analisis Orientasi}

1. Tujuan 
View bangunan pada tapak yang sesuai dengan potensi kondisi lapangan.

2. Dasar pertimbangan

a. Orientasi entrance menjadi elemen yang mengekspos keberadaan objek.

b. Orientasi ke dalam tapak dapat digunakan apabila terdapat potensi untuk diekspos. (Gambar 3)

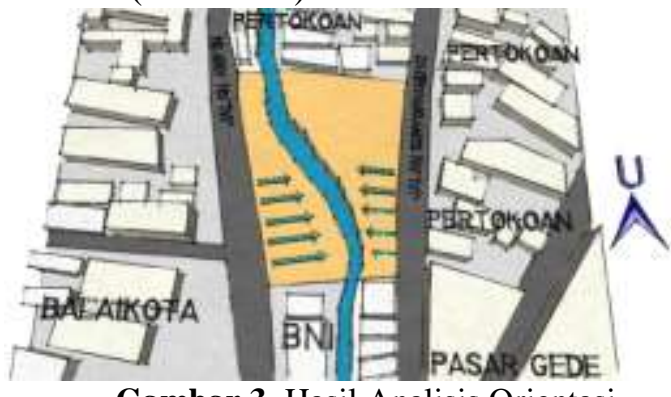

Gambar 3. Hasil Analisis Orientasi

\subsection{Analisis Peruangan}

1. Tujuan

Macam-macam ruang yang direncanakan berdasarkan pelaku, jenis kegiatan dan pola kegiatan yang terjadi di dalamnya.

2. Dasar Pertimbangan

Untuk mengetahui kebutuhan ruang yang diperlukan harus memenuhi kriteria kelompok kegiatan, pelaku kegiatan dan pola kegiatan.

3. Jenis kegiatan
a. Kegiatan wisata kuliner
b. Kegiatan pelayanan
c. Kegiatan pengelolaan
d. Kegiatan servis

\subsection{Analisis Tata Massa Bangunan}

\section{Tujuan}

Pola tatanan lansekap yang menunjang estetika dan fungsi ruang sebagai kegiatan wisata (Albert J. Rutledge, 1971).

2. Dasar pertimbangan

a. Tata massa bangunan menyesuaikan karakter tapak dan kuliner khas Kota Solo yang dinamis.

b. Pemilihan warna yang menyesuaikan tiap zoning dan dominasi warna hangat pada lansekap.

c. Penataan massa bangunan dengan proporsi yang wajar cenderung intim.

d. Pemilihan material atau bahan untuk lansekap yang didominasi material alam.

\section{KESIMPULAN}

(KONSEP DESAIN)

Desain Taman Wisata Kuliner menggunakan metode pendekatan Arsitektur Metafora yang diaplikasikan pada beberapa bagian, antara lain:

\subsection{Arsitektur Metafora Konkrit}

Pada pengaplikasian Arsitektur Metafora Konkrit, bentuk yang dimunculkan disesuaikan dengan tiap zona bangunan. Contohnya, pada zona bangunan Nasi Liwet mengaplikasikan metafora bentuk pincuk daun pisang yang difungsikan sebagai elemen kanopi (Gambar 4). Selain itu, pada area makan indoor yang menjual makanan dengan bahan baku kambing akan mengaplikasikan metafora anglo sebagai elemen furniture meja makan (Gambar 5). Begitu juga dengan area makan outdoor akan mengaplikasikan elemen meja makan dari metafora bentuk Serabi Solo (Gambar 6).

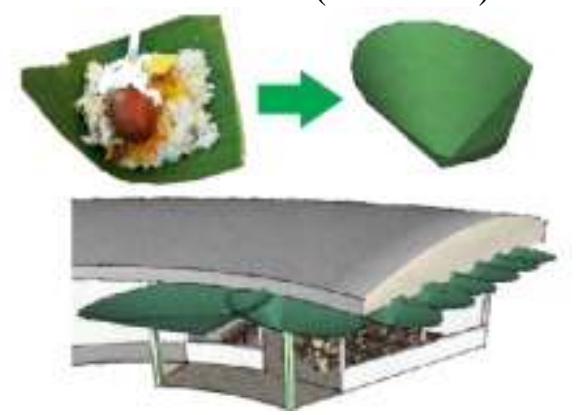

Gambar 4. Metafora Konkrit Pincuk Daun Pisang

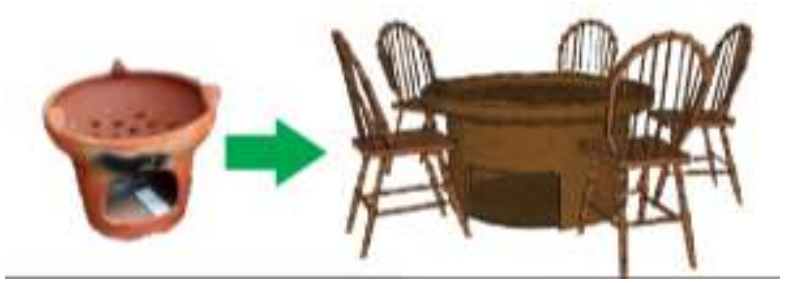

Gambar 5. Metafora Konkrit Anglo
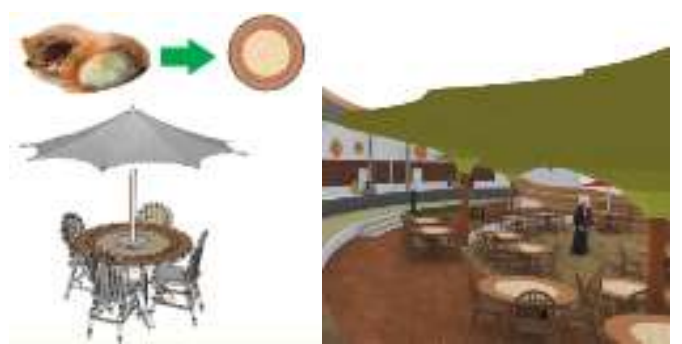

Gambar 6. Metafora Konkrit Serabi Solo 


\subsection{Arsitektur Metafora Abstrak}

Pewujudan Arsitektur Metafora Abstrak diaplikasikan dengan pembentukan nuansa dan suasana yang kental dengan kuliner khas kota Solo yang disesuaikan dengan ciri khas masing-masing kuliner, seperti nuansa lesehan dan penyajian dengan pincuk pada bangunan Nasi Liwet, nuansa kolonial pada bangunan Selat Solo, nuansa budaya Cina dan aroma dupa pada bangunan Pecinan (Gambar 7). Selain itu, juga dengan efek alunan musik tradisional khas Solo yang mengiringi kekhidmatan pengunjung dalam menikmati kuliner, serta efek pencahayaan pada malam hari yang bergunan sebagai pembentukan bayangan dan nuansa romantis dan hangat (Gambar 8).

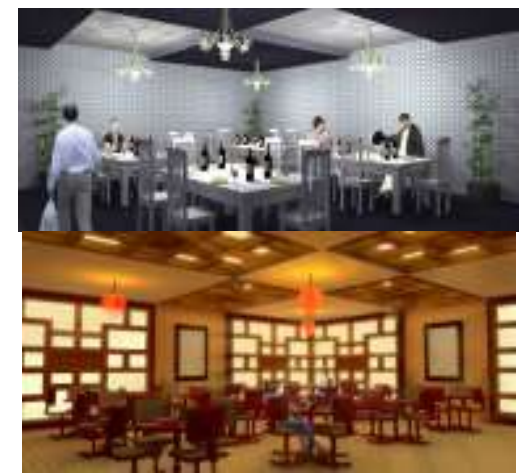

Gambar 7. Suasana Bangunan Kolonial dan Pecinan

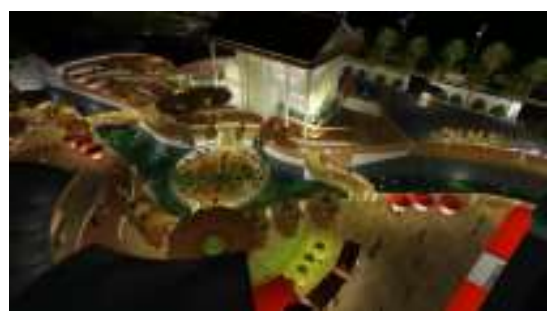

Gambar 8. Nuansa Malam Hari dengan Efek Pencahayaan

\section{REFERENSI}

Antoniades, Anthony C. 1992. Poetics of Architecture: Theory of Design. New York: Wiley.

Asfar-Solopos Digital, Adib M. "KULINER SOLO : Solo \&

Bandung Destinasi Kuliner Nomor 1 Di Indonesia." SOLOPOS.com, March 19, 2016.

http://www.solopos.com/2016/03/19/ kuliner-solo-solo-bandung-destinasikuliner-nomor-1-di-indonesia702519

CNNGo Staff. "World's 50 Best Foods," July 21, 2011.

http://travel.cnn.com/explorations/eat /worlds-50-most-delicious-foods067535/.

Dinas Kebudayaan dan Pariwisata Kota Surakarta, 2016. "Solo Culinary Destination."

http://www.surakarta.go.id/konten/so lo-culinary-destination\#overlaycontext=users/admin.

Lestari, Rose Millia. 2013. "Medan Prada House (Analogi Metafora)".

Rutledge, Albert J.1971. Anatomy of a Park: The Essentials of Recreation Area Planning and Design. Universitas Michigan: McGraw-Hill.

Walikota Surakarta. "Peraturan Daerah Kota Surakarta Nomor 1 Tahun 2012 Tentang Rencana Tata Ruang Wilayah Kota Surakarta Tahun 2011 $-2031, " 2012$. 